University of Pennsylvania Carey Law School

Penn Law: Legal Scholarship Repository

Faculty Scholarship at Penn Law

$9-24-2008$

\title{
The Walker Process Doctrine: Infringement Lawsuits as Antitrust Violations
}

Herbert J. Hovenkamp

University of Pennsylvania Carey Law School

Follow this and additional works at: https://scholarship.law.upenn.edu/faculty_scholarship

Part of the Antitrust and Trade Regulation Commons, Civil Procedure Commons, Intellectual Property Law Commons, Law and Economics Commons, and the Litigation Commons

\section{Repository Citation}

Hovenkamp, Herbert J., "The Walker Process Doctrine: Infringement Lawsuits as Antitrust Violations" (2008). Faculty Scholarship at Penn Law. 1784.

https://scholarship.law.upenn.edu/faculty_scholarship/1784

This Article is brought to you for free and open access by Penn Law: Legal Scholarship Repository. It has been accepted for inclusion in Faculty Scholarship at Penn Law by an authorized administrator of Penn Law: Legal Scholarship Repository. For more information, please contact PennlawIR@law.upenn.edu. 


\title{
The Walker Process Doctrine: Infringement Lawsuits as Antitrust Violations
}

\author{
Herbert Hovenkamp*
}

\section{Introduction}

Any patent holder, including a monopolist, may challenge an infringement of its patent or other IP rights. Of course, defending the infringement suit may prove costly to the alleged infringer. Further, if the latter's product is itself the alleged infringement, the patentee acting in good faith is entitled to notify the infringer's customers. ${ }^{1}$ Customers using infringing articles may themselves be contributory infringers ${ }^{2}$ and may therefore require indemnification security from the infringement defendant or if sufficiently frightened may stop dealing altogether. Subjecting a potential or actual rival to such burdens may weaken it or even dissuade it from beginning or continuing its rivalry with the monopolist patentee -- and perhaps without regard to the merits of the infringement claim.

As a result, suing on a patent in bad faith -- for example, where the patent was wrongfully obtained or the patentee knows that the rival is not an infringer -- is "exclusionary" in the §2 sense. Further, since improperly motivated litigation in this sense is a "sham," neither is it protected by the Noerr doctrine. ${ }^{3}$

To summarize:

${ }^{*}$ Ben V. \& Dorothy Willie Professor of Law, University of Iowa.

${ }^{1}$ E.g., Zenith Electronics Corp. v. Exzec, Inc., 182 F.3d 1340 (Fed. Cir. 1999); Super Prods Corp. v. D P Way Corp., 546 F.2d 748 (7th Cir. 1976); Deltec v. Laster, 326 F.2d 443 (6th Cir. 1964); Elkhart Brass Mfg. Co. v. Task Force Tips, Inc., 867 F.Supp. 782 (N.D. Ind. 1994). See also PennPac Intern., Inc. v. Rotonics Mfg., Inc., 2001 WL 569264 (E.D.Pa. 2001) (similar; absent bad faith the federal right to notify potential infringer's customers preempts state tort claims arising out of the notifications). Contrast Alexander v. Nat'l Farmers Org., 687 F.2d 1173, 1200-1203 (8th Cir. 1982), cert. denied, 461 U.S. 937 (1983) (harassing rivals' customers concerning pending infringement litigation not protected).

${ }^{2} 35$ U.S.C. $\S 271(a)$.

${ }^{3}$ See 1 Phillip E. Areeda and Herbert Hovenkamp, Antitrust Law Ch. 2A (3d ed. 2006) (hereinafter "Antitrust Law"). 
In Walker Process the Supreme Court declared that an infringement lawsuit based on a patent that was acquired by "fraud" could be the basis for an infringement defendant's antitrust lawsuit against the infringement plaintiff. $^{4}$ This lawsuit most typically proceeds by way of counterclaim to the infringement suit; but the courts have also approved the submission of Walker Process claims in declaratory judgment actions and even in primary lawsuits filed under the Sherman Act. ${ }^{5}$

In today's parlance "fraud" most typically refers to "inequitable conduct" by the applicant during the patent application process. But not every imperfection in a patent application process is sufficient to make a patent unenforceable. The Federal Circuit has set high standards for inequitable conduct, which require an actual intent to deceive the patent examiner and a showing of "materiality," which means that the examiner would very likely not have issued the patent had he or she known the truth. That court has set even higher standards for establishing that a lawsuit on such a patent constitutes an antitrust violation.

The realm of exclusionary practices regarding patent claims is broader than inequitable conduct, however, and covers any assertion of an IP right to exclude others while knowing that the IP right in question is unenforceable under the circumstances. The antitrust conduct can consist of such things as: (1) filing an infringement suit on a patent that the patentee knew or should have known was unenforceable as a result of inequitable conduct or other imperfections in the application process; (2) filing of an infringement suit when the infringement plaintiff knew or should have known that the rival's technology did not infringe; (3)

\footnotetext{
${ }^{4}$ Walker Process Equipment, Inc. v. Food Mach. \& Chem. Corp., 382 U.S.
} 172 (1965).

\footnotetext{
${ }^{5}$ See discussion infra.
} 
filing an infringement suit based on an expired patent. The §2 claim can also be based on exclusionary actions other than the filing of an infringement suit, such as threats to sue, writing letters to the rival's customers threatening them with contributory infringement actions while knowing that no infringement is taking place, and the like.

The antitrust conduct under $\S 2$ is an "exclusionary" practice, and as such must be evaluated as of the time it is asserted. The relevant question is whether the patentee knew or should have known at the time it filed its lawsuit or took other exclusionary action that the IP right being asserted was invalid or unenforceable in the particular situation. The conduct before the PTO is often relevant but does not necessarily determine the antitrust claim. We believe that the conduct should be evaluated by objective criteria.

In all cases involving §2 the conduct must be reasonably capable of creating, enlarging or prolonging monopoly power by impairing the opportunities of rivals. ${ }^{6}$ This entails that the exclusionary force of the conduct must be evaluated for its effect on price and output in a properly defined antitrust market. Often this will require the tribunal to assess the exclusionary power of the improperly asserted patent itself; however, in a monopoly maintenance case it may be sufficient to show that the infringement plaintiff has a dominant market share in the business from which exclusion of the rival is threatened. When such power or competitive effects are lacking, the person targeted by a bad faith IP claim may have a state law tort action for fraud or malicious prosecution.

Fraud, inequitable conduct, and other improprieties

Wrongfully brought infringement actions can be based on fraudulently obtained patents, and in those cases the fraud or ed. 2008).

${ }^{6}$ See 3 Phillip E. Areeda and Herbert Hovenkamp, Antitrust Law $1651 a$ (3d 
inequitable conduct in obtaining the patent establishes the impropriety of the subsequent infringement action -- one who acted fraudulently in obtaining a patent necessarily knows its patent is unenforceable. $^{7}$ But infringement actions can also be qualifying exclusionary practices under $\S 2$ when they are based on valid patents that are known by the infringement plaintiff to be unenforceable as a result of improprieties in procurement, or on valid patents but where the infringement plaintiff knew or should have known that the infringement defendant was not an infringer. ${ }^{8}$ Wrongfulness can also be established when the infringement plaintiff bases its cause of action on unreasonable and clearly incorrect interpretations of questions of law. For example, an action for contributory infringement is proper against one who sells a nonstaple good under circumstances where the buyer of the good must infringe the patent in order to make use of the good. ${ }^{9}$ But an action against the manufacturer of a staple good with numerous non-infringing uses would be clearly contrary to law and thus presumably brought in bad

\footnotetext{
${ }^{7}$ Of course, principles of res judicata apply. See Abbott Laboratories $v$. Mylan Pharmaceuticals, Inc., 2007-1 Trade Cas. \75617 (N.D.III. Feb. 23, 2007) (infringement defendant/counterclaimant adequately alleged Walker Process violation; while the court could take judicial notice of another decision finding that patentee had not engaged in inequitable conduct before PTO [Abbott v. Torpharm, 2006 WL 2458717 (N. D. III. 2004)], Mylan was not a party to that litigation and thus the facts found there were not dispositive as to it; citing GE Capital Corp. v. Lease Resolution Corp., 128 F.3d 1074, 1083 (7th Cir. 1997) (a court "cannot achieve through judicial notice what it cannot achieve through collateral estoppel" when the plaintiff in a subsequent action was not a party to the previous action and "has never been afforded an opportunity to present its evidence and arguments on the claim")).

${ }^{8}$ See, e.g., United States v. Besser Mfg. Co., 96 F.Supp. 304, 312 (E.D.Mich. 1951), aff'd 343 U.S. 444 (1952) (lawsuits on machine alleged to infringe but that patentee had never examined); Jarrow Formulas, Inc. v. International Nutrition Co., 175 F. Supp. 2d 296, 313-314 (D. Conn. 2001) (antitrust claim survived motion to dismiss where it alleged that defendant's prior patent infringement action was objectively baseless because it did not reasonably have ownership of the patent in question). Suits for contributory infringement against those making products complementary to the patented product could also qualify as exclusionary practices. Such suits are authorized in 35 U.S.C. §271(d); §271(c) of that statute defines contributory infringement.

${ }^{9}$ For the definition of contributory infringement and further explanation, see 10 Phillip E. Areeda, Einer Elhauge and Herbert Hovenkamp, Antitrust Law T1781b (2d ed. 2003).
} 
faith. $^{10}$

The important difference between infringement actions based on fraudulently procured patents and other improper infringement actions is that for the latter the conduct in obtaining the patent does not in and of itself establish impropriety. It must additionally be established that the enforcer knew or should have known at the time of bringing the suit that the patent was unenforceable under the circumstances in question. Nevertheless, this difference is readily exaggerated. The all important question in either circumstance is whether the patentee has (1) committed an exclusionary act that is (2) not authorized by the patent law.

The exclusionary act is most generally a patent infringement suit, or in some cases another assertion of the patent's exclusionary power. As a result the wrongfulness of the act must be assessed as of the time it is asserted. As a general proposition, merely obtaining a patent by fraud, with no subsequent enforcement attempt, is not an exclusionary practice under $\$ 2 .{ }^{11}$ Once the infringement action is filed the relevant question becomes whether the infringement plaintiff knew or should have known that the action is improper, and this can result from any deficiency including but not limited to fraud or inequitable conduct before the PTO.

Typically, but not always, the antitrust claim is a compulsory counterclaim to the underlying infringement suit. First, the patentee files its infringement action. Then, the infringement defendant ${ }^{12}$ answers that the asserted patent is invalid or unenforceable under the circumstances, or that the infringement defendant's technology

\footnotetext{
${ }^{10}$ See, e.g., Dawson Chem. Co. v. Rohm \& Haas Co., 448 U.S. 176 (1980); and 35 U.S.C. $\$ 271(c)$, whose provision on contributory infringement expressly excludes "a staple article or commodity of commerce suitable for substantial noninfringing use...."

${ }^{11}$ See Cygnus Therapeutic Systems v. ALZA Corp., 92 F.3d 1153 (Fed. Cir. 1996). On the possibility of a proceeding under the Federal Trade Commission

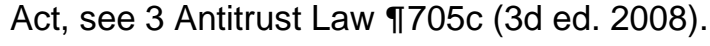

${ }^{12}$ To simplify the exposition this Paragraph uses the terms "infringement plaintiff" and "infringement defendant" to refer to the original parties to an infringement action; and "antitrust plaintiff" and "antitrust defendant" to refer to the parties with respect to the antitrust countersuit.
} 
does not infringe. In addition, the infringement defendant counterclaims, alleging that the unwarranted infringement action is itself monopolization or an attempt to monopolize a market covered by or related to the patent in question.

In Nobelpharma ${ }^{13}$ the Federal Circuit explored the relationship between the Supreme Court's Professional Real Estate (PRE) decision $^{14}$ and its earlier Walker Process conclusion ${ }^{15}$ that obtaining a patent by fraud and then attempting to enforce it could constitute an antitrust violation. The infringement plaintiff had filed suit on a patent that was found to be invalid for failure to disclose the best mode for carrying out an invention. The main purpose of this requirement is to permit those examining the patent to learn the best mode for applying the invention without undue experimentation, thus facilitating the entry of the innovation into the public domain once the patent expires. In this case the Swedish patentee had additional information about the best mode for carrying out its invention, but that information was not disclosed and did not appear in the application for a United States patent. The jury concluded from this evidence that the patent had been obtained by fraud. ${ }^{16}$

The court indicated that antitrust liability for an improperly brought patent infringement suit can be established by one of two alternative routes:

A patentee who brings an infringement suit may be subject to antitrust liability for the anti-competitive effects of that suit if the alleged infringer (the antitrust plaintiff) proves (1) that the asserted patent was obtained through knowing and willful fraud within the meaning of Walker Process ..., or (2) that the infringement suit was "a mere sham to cover what is actually nothing more than an attempt to interfere directly with the

${ }^{13}$ Nobelpharma $A B$ v. Implant Innovations, 141 F.3d 1059 (Fed. Cir.), cert. denied, 525 U.S. 876 (1998) (vacating and withdrawing the previous panel opinion published at 129 F.3d 1463 (Fed. Cir. 1997).

${ }^{14}$ See Prof'l Real Estate Investors, Inc. v. Columbia Pictures Indus., Inc., 508 U.S. 49 (1993) ("PRE").

${ }^{15}$ See note 4.

${ }^{16}$ Nobelpharma, 141 F.3d at 1062. 
business relationships of a competitor...."17

The court then noted Justice Harlan's Walker Process concurrence seeking to distinguish patents obtained by deliberate fraud from patents "rendered invalid or unenforceable for other reasons...." ${ }^{18}$ He feared that permitting private antitrust challenges to

also reach monopolies practiced under patents that for one reason or another may turn out to be voidable under one or more of the numerous technicalities attending the issuance of a patent, might well chill the disclosure of inventions through the obtaining of a patent because of fear of the vexations or punitive consequences of treble-damage suits.

The Federal Circuit then observed that:

Consistent with the Supreme Court's analysis in Walker Process, as well as Justice Harlan's concurring opinion, we have distinguished "inequitable conduct" from Walker Process fraud, noting that inequitable conduct is a broader, more inclusive concept than the common law fraud needed to support a Walker Process counterclaim. ${ }^{19}$

Fraud was defined the in the common law sense as:

(1) a representation of a material fact, (2) the falsity of that representation, (3) the intent to deceive or, at least, a state of mind so reckless as to the consequences that it is held to be the equivalent of intent (scienter), (4) a justifiable reliance upon the misrepresentation by the party deceived which

\footnotetext{
${ }^{17}$ Nobelpharma, id. at 1068, citing Eastern R.R. Presidents Conference v. Noerr Motor Freight, Inc., 365 U.S. 127, 144 (1961), and Cal. Motor Transp. Co. v. Trucking Unlimited, 404 U.S. 508, 510 (1972).

${ }^{18}$ Id. at 1069, quoting Walker Process, note 4, 382 U.S. at 179-80 (Harlan, J., concurring).

${ }^{19}$ Nobelpharma, 141 F.3d at 1069. See also DDAVP Direct Purchaser Antitrust Litigation, 2007-1 Trade Cas. 975726 (S.D.N.Y. Nov. 2, 2006) (mere inequitable conduct as opposed to fraud before PTO insufficient to create Walker Process claim on part of purchasers).
} 
induces him to act thereon, and (5) injury to the party deceived as a result of his reliance on the misrepresentation. ${ }^{20}$

Clearly, a patent might be invalid or unenforceable for reasons falling short of fraud in this common law sense. Further, an infringement action might be improper even though the patent is valid -- as, for example, when the patentee knows that the infringement defendant's technology does not infringe because none of the claims in the asserted patent cover it. ${ }^{21}$

The court then addressed an issue left undecided by the Supreme Court in its PRE decision"2 -- namely, how "Noerr applies to the ex parte application process," and particularly, "how it applies to the Walker Process claim." ${ }^{23}$ The Federal Circuit itself had twice refused to resolve this issue. ${ }^{24}$ The court then concluded:

PRE and Walker Process provide alternative legal grounds on which a patentee may be stripped of its immunity from the antitrust laws; both legal theories may be applied to the same conduct. Moreover, we need not find a way to merge these decisions. Each provides its own basis for depriving a patent owner of immunity from the antitrust laws; either or both may be applicable to a particular party's conduct in obtaining and

\footnotetext{
${ }^{20}$ Nobelpharma, 141 F.3d at 1069-1070. See also Unitherm Food Sys., Inc. v. Swift-Eckrich, Inc., 375 F.3d 1341, 1358 n.5 (Fed. Cir. 2004), rev'd on nonantitrust grds., 546 U.S. 394 (2006) (repeating these requirements; ultimately rejecting antitrust claim for failure to show relevant market; on intent, the court stated that "a state of mind so reckless as to the consequences that it is held to be the equivalent of intent" will suffice to show fraud).

${ }^{21}$ In the copyright context, see $P R E$, note 14 , where the validity of the infringement plaintiff's copyright was not in dispute; rather, the antitrust counterclaim was based on the legal theory that the compensated playing of a videodisc in a hotel room was not an infringement of the copyright.

${ }^{22}$ See note 14.

${ }^{23}$ Nobelpharma, 141 F.3d at 1071, quoting district court opinion, 930 F.Supp. at 1253 , which was in turn referring to PRE, note 14,508 U.S. at 61 n. 6.

${ }^{24}$ Nobelpharma, 141 F.3d at 1071, citing FilmTec Corp. v. Hydranautics, 67 F.3d 931, 939 n. 2 (Fed.Cir.1995), cert. denied, 519 U.S. 814 (1996); Carroll Touch, Inc. v. Electro Mech. Sys., Inc., 15 F.3d 1573, 1583 n. 10 (Fed.Cir.1993).
} 
enforcing a patent. The Supreme Court saw no need to merge these separate lines of cases and neither do we. ${ }^{25}$

First, the court held, if the fraud elements of the Walker Process claim could be made out, as well as the "other criteria" for antitrust liability, ${ }^{26}$ "such liability can be imposed without the additional sham inquiry required under PRE." ${ }^{27}$ That is, assuming the patent was procured by fraud and the other elements of an antitrust claim were met, an infringement suit based on that patent encountered automatic antitrust liability.

By contrast,

irrespective of the patent applicant's conduct before the PTO, an antitrust claim can also be based on a PRE allegation that a suit is baseless; in order to prove that a suit was within Noerr's "sham" exception to immunity, an antitrust plaintiff must prove that the suit was both objectively baseless and subjectively motivated by a desire to impose collateral, anti-competitive injury rather than to obtain a justifiable legal remedy. ${ }^{28}$

As the court explained:

Thus, under PRE, a sham suit must be both subjectively brought in bad faith and based on a theory of either infringement or validity that is objectively baseless. Accordingly, if a suit is not objectively baseless, an antitrust defendant's subjective motivation is immaterial. In contrast with a Walker Process claim, a patentee's activities in procuring the patent are not necessarily at issue. It is the bringing of the lawsuit that is subjectively and objectively baseless that must be proved. ${ }^{29}$

\footnotetext{
${ }^{25}$ Nobelpharma, 141 F.3d at 1071.
}

${ }^{26}$ On these other requirements, see 1 Antitrust Law \208 ("sham" filings constitute only the conduct element of antitrust offense).

${ }^{27}$ Nobelpharma, 141 F.3d at 1071.

${ }^{28}$ Nobelpharma, id. at 1071, citing PRE, 508 U.S. at 60-61.

${ }^{29}$ Nobelpharma, 141 F.3d at 1072. 
In sum, in the Federal Circuit's conception the "bringing of the lawsuit" was the relevant antitrust act for a PRE style claim, while it was the patentee's actions in procuring its patent that were relevant to the Walker Process antitrust claim. To us, the two actions do not differ all that much, and the "bringing of the lawsuit" or similar exclusionary activity is in fact the gravamen of both offenses.

In Nobelpharma the court found substantial evidence from which a jury could have reached factual conclusions that would "strip NP [the infringement plaintiff] of its immunity from antitrust liability." ${ }^{30}$ This evidence indicated that the patentee had fraudulently failed to disclose information to the PTO that would have prevented the patent from being issued. Evidence in the record supported a finding of Walker Process fraud on all of the elements listed above. Further, there was evidence that the defendant brought its infringement suit with knowledge that the patent application had been fraudulent. ${ }^{31}$

Nevertheless, the distinctions between Walker Process antitrust liability and liability for "sham" infringement litigation are somewhat elusive. First, while Walker Process itself spoke as if "obtaining" a patent by fraud was the gravamen of the antitrust defense ${ }^{32}$ the actual facts were that the patent holder was bringing an infringement action. As noted previously, simply obtaining a patent fraudulently with no subsequent enforcement activity does not violate the Sherman Act, although it may violate the FTC Act. ${ }^{33}$ Of course, one might enforce a fraudulently obtained patent in other ways than by making or threatening infringement actions. For example, one might simply assert the patent and warn a potential rival to stay out of the market the patent assertedly covers; or one might insist on collecting a royalty for technology allegedly covered by such a patent. Clearly a patent obtained by fraud could be used

${ }^{30}$ Nobelpharma, id. at 1073.

${ }^{31}$ Nobelpharma, 141 F.3d at 1072.

${ }^{32}$ See Walker Process, note 4, 382 U.S. at 174, sustaining an amended counterclaim alleging that the antitrust defendant "illegally monopolized interstate and foreign commerce by fraudulently and in bad faith obtaining and maintaining ... its patent ... well knowing that it had no basis for ... a patent...." 11.

${ }^{33}$ The Federal Circuit recognizes this proposition. See, Cygnus case, note 
in an anticompetitive way falling short of an infringement suit. Whether such practices are sufficiently exclusionary so as to violate the antitrust laws cannot be stated categorically.

Second, once an infringement action is brought or threatened $^{34}$ then the "sham" issue is addressed first by considering whether the lawsuit is objectively baseless. ${ }^{35}$ A large number of defects could render a lawsuit objectively baseless, including but not limited to these: (1) the patent may have been procured by fraud in the Walker Process sense, and thus be invalid and unenforceable; ${ }^{36}$ (2) the patent may be rendered unenforceable by inequitable conduct before the PTO or by other knowledge or activities falling short of fraud; (3) The patent may have expired; ${ }^{37}$ (4) the patent may be valid and enforceable, but the infringement plaintiff may know or should have known that the infringement defendant's technology does not infringe the patent; ${ }^{38}$ (5) the infringement defendant's actions may be lawful as a result of a previously granted license; ${ }^{39}$

\footnotetext{
${ }^{34}$ On Noerr protection for threatened litigation, provided it is not a "sham," see 1 Antitrust Law I205e. See also Christopher R. Leslie, Patents of Damocles, 84 IND. L.J. (2008) (advocating antitrust remedy).

${ }^{35}$ See 1 Antitrust Law $\mathbb{2} 205 b$.

${ }^{36}$ Cf. Open LCR.Com, Inc. v. Rates Tech., Inc.., 112 F.Supp.2d 1223 (D.Colo. 2000) (plaintiff's allegations that patentee failed to disclose prior art to PTO and then threatened and brought infringement claims without realistic expectation of success on merits, even after antitrust plaintiff documented the existence of the prior art, were sufficient to support antitrust action).
}

${ }^{37}$ See International Tech. Consultants, Inc. v. Pilkington PLC, 137 F.3d 1382 (9th Cir. 1998) (infringement suit based on expired patents a possible antitrust violation).

${ }^{38} \mathrm{Cf}$. Besser case, note 8 (infringement plaintiff did not have good reason to believe that infringement defendant's technology infringed); Moore USA, Inc. v. Standard Register Co., 139 F.Supp. 2d 348 W.D.N.Y. 2001) (refusing to dismiss Sherman $\$ 2$ counterclaim allegation that patentee filed infringement claim while knowing that counterclaimant's product did not infringe because it did not incorporate an essential ingredient); Ecrix Corp. v. Exabyte Corp., 95 F.Supp.2d 1155 (D.Colo. 2000) (for purposes of filing antitrust claim, infringement defendant was entitled to discovery of factual basis for infringement plaintiff's allegations that former's technology infringed the latter's patent).

${ }^{39}$ Cf. Glass Equip. Dvlpmnt. v. Besten, 174 F.3d 1337 (Fed.Cir. 1999) (patentee sued for infringement; alleged infringer claimed it had an implied license to use the patented technology and filed antitrust counterclaim; court finds no 
(6) there may be a legal or jurisdictional rule that makes the infringement suit improper as a matter of law. ${ }^{40}$

Third, the Nobelpharma decision concluded that if the infringement defendant (antitrust plaintiff) shows that a patent was obtained by fraud, then the unreasonableness of the infringement suit has automatically been established. As a result no additional jury instructions under PRE or Noerr are required. ${ }^{41}$ The court did not indicate what these instructions would have been, but apparently they would have advised the jury that the right to bring an infringement suit is broad and cannot be limited except for a proven sham. But in that case the difference between a Walker Process fraud case and a PRE-style infringement action is small, and revolves only around the necessity of bringing an additional jury instruction that, while unnecessary in the first, would have been advisable in any event, given that the jury might have failed to find fraud but might have found other conduct rendering the lawsuit a sham.

The Nobelpharma decision thus seems to exaggerate the

implied license, which entails that infringement claim was well founded; thus no antitrust violation).

${ }^{40} \mathrm{Cf}$. PRE, note 14 (copyright infringement action not improperly brought where circuits were divided on a dispositive question of law and one had sided with the infringement plaintiff's position); Mitek Surg. Prods., Inc. v. Arthrex, Inc., 230 F.3d 1383, 2000 WL 217637, 2000-1 Trade Cas. 172803 (Fed. Cir. 2000, unpub.) (two different district courts had disagreed on claim construction of patent subject to infringement action; patentee entitled to bring infringement action relying on the favorable district court holding). As a general matter, claim construction presents a question of law. See also Markman v. Westview Instr., Inc., 517 U.S. 370 (1996); IMS Tech., Inc. v. Hass Automation, Inc., 206 F.3d 1422, 1429 (Fed. Cir. 2000), cert. dismissed, 530 U.S. 1299 (2000); Vitronics Corp. v. Conceptronic, Inc., 90 F.3d 1576 (Fed. Cir. 1996). A lawsuit in one court based on a claim construction broader than that given in one or more other courts raises issues analogous to those in PRE. See Herbert Hovenkamp, Mark D. Janis \& Mark A. Lemley, Intellectual Property and Antitrust Law §2.2c (2001 \& 2007 Supp.). Cf. Goss Int'I Americas, Inc. v. MAN Roland, Inc., 2007-1 Trade Cas. 175632 (D.N.H. Mar. 12, 2007) (denying Walker Process claim based on alleged inequitable conduct in procurement of a different patent than the one being enforced when it could not be shown that inequitable conduct in procurement of one patent would have invalidated the second patent).

\footnotetext{
${ }^{41}$ See Nobelpharma, note 13, 141 F.3d at 1073.
} 
difference between situations in which an infringement action is unwarranted because the patent was obtained by fraud, and those where the action is unwarranted as a result of other defects that the infringement plaintiff clearly knew or (measured objectively) should have known. The all important question in both is whether a reasonable actor in the infringement plaintiff's position should have known at the time of the lawsuit that the infringement action or other exclusionary conduct was legally inappropriate under the circumstances. Fraud in obtaining a patent is only one of many circumstances rendering the infringement action inappropriate. ${ }^{42}$

Further, while failing to require the Noerr/PRE instruction may have been harmless error in the case at hand, that would not always be so. First, if the jury found no fraud but found other reasons why the suit should not have been brought, failure to give the instruction might require a new trial. In such a case there must be a conclusion that the lawsuit was objectively baseless, and this question could be one of fact, depending on the circumstances. Second, there may be situations in which even an infringement lawsuit based on a fraudulently procured patent could not be the basis of an antitrust counterclaim. Consider, for example, the patentee who obtains its patent by fraud and then transfers it or gives an exclusive license to an innocent acquirer. The acquirer, not knowing of the fraud, believes its enforcement right to be valid and brings an infringement suit. In such a case it would be the infringement plaintiff's actual or objective knowledge at the time of the infringement suit that would establish its antitrust culpability.

Whatever the limits on unfounded suits generally, the monopolist burdening a rival with a bad faith suit clearly commits an exclusionary act. At the same time, however, even the monopolist is

\footnotetext{
${ }^{42}$ Consider the Supreme Court's decision in KSR Intern. Co. v. Teleflex, Inc., 127 S.Ct. 1727 (2007), which changed the patentability standard of obviousness, holding that the Federal Circuit had not been sufficiently strict in cases where someone reasonably skilled in the art could have anticipated the patent claim, even in a different field. At this writing it is too early to assess the impact of $K S R$ on antitrust challenges to infringement actions. Quite possibly, however, a certain class of patents previously thought valid will now be invalid under the KSR standard. One who brought suit on such a patent knowing of the almost certain invalidity might reasonably be subjected to an antitrust counterclaim. This would be an example of a change in a rule of law that subsequently rendered a certain class of patents invalid.
} 
entitled to protect its property rights. Too expansive a conception of baselessness could turn many infringement actions into antitrust claims against the infringement plaintiff, thus putting the patent owner at peril even in defending its own property rights. ${ }^{43}$

As noted before some cases do not involve a filed infringement action at all, but only a threat to sue or communications to customers. ${ }^{44}$ For example, consider the monopolist who -knowing its patent to be invalid -- writes a letter to a rival's customers threatening infringement actions if they continue buying from the rival. ${ }^{45}$ The customers are very likely in an even poorer position than the rival to know about the patent's invalidity. Further, the cost to a customer of switching its patronage may be far lower than the cost to the rival of defending any infringement action. Indeed, acting under uncertainty the customers may switch rather than accept any apparent risk of litigating a costly infringement suit. ${ }^{46}$

"Sham" infringement claim or enforcement action satisfies \$2 conduct requirement; tort law alternative

The improper patent infringement suit serves to establish the conduct element of a $\$ 2$ claim. ${ }^{47}$ In addition the antitrust plaintiff

${ }^{43}$ Antitrust's Noerr doctrine generally deals with these issues. See Ch. $2 \mathrm{~A}$.

${ }^{44}$ See Va. Panel Corp. v. MAC Panel Co., 133 F.3d 860 (Fed. Cir. 1997), cert. denied, 525 U.S. 815 (1998) ("The antitrust laws do not preclude patentees from putting suspected infringers on notice of suspected infringement).

${ }^{45}$ See, e.g., Johnson v. Con-Vey/Keystone, Inc., 856 F.Supp. 1443 (D.Or. 1994) (notifying rivals' customers concerning patent infringement suit not protected by Noerr). Compare Oetiker v. Jurid Werke GmbH, 671 F.2d 596, 601 (D.C. Cir. 1982) (letter, ignored by plaintiff's suppliers, stating without bad faith that patent holder "would be forced to vindicate its patent right if no settlement proposal were received" constituted "neither a threat nor an enforcement sufficient to trigger the antitrust laws").

${ }^{46}$ See Goss Int'l Americas, Inc. v. MAN Roland, Inc., 2006 WL 1575287, 2006-2 Trade Cas. \75392 (D.N.H. June 2, 2006) (Walker Process claim did not require that owner of fraudulently obtained patent actually file patent infringement suit; warning letters or other threats based on such a patent could suffice; relying on Unitherm Food Sys., Inc. v. Swift-Eckrich, Inc., 375 F.3d 1341, 1344-45, 135758 (Fed. Cir. 2004), rev'd in part on other grds., 126 S.Ct. 980 (2006).




must show the relevant market power requirement, which can be in the implicated patent itself, or in the patentee's underlying market share in a monopoly maintenance case.

If the infringement plaintiff lacks substantial power in a relevant market but for the patent, then the antitrust plaintiff must show that the patent itself is sufficient to confer this power or dangerously threaten to do so, thus making the improper suit an exclusionary practice in the $\$ 2$ sense. However, if the infringement plaintiff already has substantial power in the relevant market, then an improper infringement action on any patent tending to exclude rivals could be unlawfully exclusionary, even if that patent itself did not dominate a market. ${ }^{48}$ Finally, the evidence as a whole must be sufficient to give rise to an inference of harm to competition.

When these structural preconditions for an antitrust violation are lacking, the infringement defendant might nevertheless be able to pursue a state tort claim for common law fraud, malicious prosecution, or a related offense. ${ }^{49}$ The important difference

${ }^{48}$ See Netflix, Inc. v. Blockbuster, Inc., 2006 WL 2458717 (N.D.Cal. Aug. 22, 2006) (antitrust claimant sufficiently alleged power with claim that infringement plaintiff possessed 65 percent of market for internet DVD movie rentals).

See also Golan v. Pingel Enterp., Inc., 310 F.3d 1360 (Fed. Cir. 2002) (even if assertions of patent were improper, there was no antitrust violation because patentee was not shown to have market power in its patented product); William Wrigley, Jr., Co. v. Cadbury Adams USA, LLC, 2005 WL 936928, 2005-1 Trade Cas. $₫ 74,780$ (N.D. 111. Apr. 22, 2005) (refusing to dismiss Walker Process counterclaim that patent infringement action violated §2; rejecting antitrust defendant's argument that because basis of claim was that patent was invalid, antitrust plaintiff could not show dangerous probability of success in creating a monopoly-note that even if patent is significant contributor to market power, basis of claim is that antitrust defendant was misusing infringement action so as to give recognition to the patent); Medtronic AVE, Inc. v. Boston Scientific Corp., 2001 WL 652016, 2001-2 Trade Cas. \73,388 (D. Del. March 30, 2001) (patentee could have violated $\S 2$ by bringing infringement action on patent procured by fraud; while counterclaim did not allege patentee's market share, there were other ways of measuring market power); E-Z Bozuz, L.L.C. v. Prof'l Product Research Co., Inc., 2003 WL 22068573 (S.D.N.Y. Sept. 5, 2003) (rejecting antitrust counterclaim to patent infringement suit where infringement defendant did not claim that patentee had market power in its patented hand-tied bow maker).

${ }^{49}$ On the relationship between baseless suits and state law malicious prosecution claims, see Hydranautics v. Filmtec Corp., 204 F.3d 880, 886 (9th Cir. 2000) (Federal Circuit's determination that patent infringement suit was not objectively basis because genuine factual issues existed about validity of patent, 
between such common law claims and the antitrust claim is that the former equate the wrong with the conduct itself rather than with the threat of monopoly. Of course, treble damages and attorneys fees are very likely not available for such a claim.

\section{Objective Standard}

Infringement claims can range from a bad faith suit actually known by its plaintiff to be groundless, to a "carelessly" brought action, to a reasonable but uncertain suit, and to one that is both sure and actually successful. Often reliable evidence about the infringement plaintiff's subjective mental state will be unavailable. In any event, in the case of valid claims mental state is irrelevant, for the patentee just as any property owner can enforce its rights no matter what its intent. ${ }^{50}$

In any event, objective evidence about what is reasonable under the circumstance often provides a basis for determining the reasonableness of the infringement claim. Requiring objective baselessness also encourages reasonable care in subjecting rivals to the burdens of an infringement action. Accordingly, a monopolist's careless challenges made without adequate inquiry into underlying

did not collaterally estop subsequent Ninth Circuit malicious prosecution action challenging same infringement suit; while "objectively baseless" standard governed both claims, in the malicious prosecution claim the infringement defendant also raised issues of fraud on the patent office and perjury during course of infringement trial). Cf. Conroy v. Fresh Del Monte Produce, Inc., $325 \mathrm{~F}$. Supp. 2d 1049,1056 (N.D. Cal. 2004). When Del Monte threatened to enforce patents on its hybrid pineapples the plaintiff filed a state law antitrust and unfair competition claim, which Del Monte then removed to federal court. The latter court then granted the plaintiff's motion to remand to state court, holding that the federal court lacked jurisdiction because no patent issues were raised because no infringement suit had been filed and the threats had been made with respect to non-infringing pineapples; as a result the patent laws were not implicated.

Cf. Assessment Technologies v. Wiredata, Inc., 350 F.3d 640 (7th Cir. 2003); 361 F.3d 434 (7th Cir. 2004) (improper copyright infringement lawsuit designed to exclude others from uncopyrightable data could be copyright misuse; conduct alleged as tortious malicious prosecution).

${ }^{50}$ See, e.g., Independent Service Org. (ISO) Antitrust Litig., 203 F.3d 1322 (Fed. Cir. 2000), cert. denied, 531 U.S. 1143 (2001) (since validity of Xerox's patent had not been disputed, the attempt to enforce them via an infringement counterclaim could not be baseless). 
facts or law should also be regarded as improper.

In Professional Real Estate (PRE) the Supreme Court held that a copyright (not patent) infringement suit is immune from antitrust challenge unless it is baseless, with baselessness measured by an objective standard. ${ }^{51}$ Importantly, the "baselessness" question in PRE referred entirely to the reasonableness of the infringement plaintiff's interpretation of the federal copyright statute as a matter of law. The decision expressly deferred the question of antitrust immunity if the infringement plaintiff engaged in "fraud or other misrepresentations" of fact. ${ }^{52}$

The relevant points respecting $P R E$ are these:

(1) If the disputed question in the patent infringement suit is entirely a question of law -- as, for example, whether the infringement plaintiff's interpretation of a particular patent doctrine is objectively reasonable ${ }^{53}$-- then PRE immunizes any antitrust challenge to the infringement action when the infringement suit itself is objectively well founded. These are essentially the facts of the PRE case itself, except that it involved copyright rather than patent law.

(2) PRE does not explicitly apply to the more usual case where the question in the patent infringement suit involves a disputed matter of fact or complex mixed questions of law and fact. ${ }^{54}$ This could include such issues as whether the infringement

${ }^{51}$ See note 14, 508 U.S. 49. Cf. B.V. Optische Industrie de Oude Delft v. Hologic, Inc., 909 F.Supp. 162 (S.D.N.Y. 1995) (fact that patent infringement suit was settled does not establish conclusively that it could not be an antitrust violation; to be sure, the cost of settling might be less than the cost of litigating, but one must query whether the infringement defendant's willingness to settle indicates that the suit must not have been objectively baseless).

${ }^{52}$ Id. at 1929 n.6. The Court cited the majority's and Justice Harlan's concurring opinion in Walker Process, note 4, 382 U.S. at 176-177, 179-180, both of which noted that unjustified claims made in patent infringement suits typically involve false allegations of fact rather than irrational theories of law.

${ }^{53}$ E.g., Mitek Surgical, note 40, where the infringement claim depended on the claim construction given to the patent, which is a question of law.

${ }^{54}$ E.g., Carroll Touch, note 24. 
defendant's conduct actually constitutes infringement, or whether information in the infringement plaintiff's possession or infirmities in the patent application process renders the patent invalid or unenforceable -- for example, where the patentee lied about disqualifying prior sales. ${ }^{55}$ But if the infringement plaintiff has made an objectively reasonable investigation and has an objectively reasonable basis for believing that its patent is valid, enforceable, and infringed under the circumstances, then its infringement suit enjoys antitrust immunity even if the court should subsequently disagree and find the patent invalid, unenforceable, or not infringed. $^{56}$

(3) If the patent infringement claim succeeds antitrust immunity is automatic, ${ }^{57}$ subject to one important exception: if it should subsequently be determined that the claim's success depended on information which the patentee know or should have known at the time of presenting it to be false, then the suit could still be a "sham" and thus satisfy the conduct requirement for a §2 claim. Although some dicta in the PRE decision might be read to immunize any successful suit, the facts of that case involved only a disputed question of law and the decision cannot be read to immunize a lawsuit that was successful only because of fraudulently made factual misrepresentations in the course of litigation. ${ }^{58}$

${ }^{55}$ E.g., Dippin' Dots, Inc. v. Mosey, 476 F.3d 1337 (Fed. Cir. 2007), cert. denied, 128 S.Ct. 375 (2007) (applicant lied in application about disqualifying sales made more than one year prior to application).

${ }^{56}$ Note that as many as half of patents, once committed to litigation, are found to be invalid. See John R. Allison \& Mark A. Lemley, Empirical Evidence on the Validity of Litigated Patents, 26 AIPLA Q.J. 185, 205 (1998) (finding about 46\% of litigated patents to be invalid).

${ }^{57}$ See Filmtec, note 24, 67 F.3d at 936. And see Contour Chair Lounge Co. v. True-Fit Chair, Inc., 648 F. Supp. 704 (E.D. Mo. 1986) (antitrust liability for baseless infringement suit cannot obtain when the patent was found to be valid).

${ }^{58}$ To illustrate, the patentee whose patent was unenforceable because it swore to the PTO that there were no disqualifying prior sales, when such sales had actually occurred, might succeed in a subsequent infringement suit if evidence of the prior sales was not exposed. But if exposed later, such evidence might serve both to invalidate the patent and support the antitrust claim. See the discussion infra of Dippin' Dots, note 55.

See Hydranautics v. Filmtec Corp., 224 Fed.Appx. 675, 2007-1 Trade Cas. I775646 (9th Cir. Mar. 16, 2007, unpublished) (success in the underlying patent 
(4) In PRE the Supreme Court also said this in dicta:

Only if challenged litigation is objectively meritless may a court examine the litigant's subjective motivation. Under this second part of our definition of sham, the court should focus on whether the baseless lawsuit conceals "an attempt to interfere directly with the business relationships of a competitor ... through the "use [of] the governmental process--as opposed to the outcome of that process--as an anticompetitive weapon." This two-tiered process requires the plaintiff to disprove the challenged lawsuit's legal viability before the court will entertain evidence of the suit's economic viability. Of course, even a plaintiff who defeats the defendant's claim to Noerr immunity by demonstrating both the objective and the subjective components of a sham must still prove a substantive antitrust violation. Proof of a sham merely deprives the defendant of immunity; it does not relieve the plaintiff of the obligation to establish all other elements of his claim. ${ }^{59}$

This language suggests that the $\$ 2$ claim includes a "subjective" as well as an "objective" element. These dicta should not be read to require inquiry into the infringement plaintiff's actual state of mind. Here, as anywhere else, intent can be inferred from sufficiently unambiguous conduct. Consider the patentee who himself made sales prior to the patent application that would have barred patentability of disclosed. The Patent Act's on sale bar prevents patenting of a product that was sold more than a year prior to the filing of the initial patent application. ${ }^{60}$ The applicant signed a

infringement suit created a presumption that the suit was properly brought which could be rebutted only by a showing of fraud or perjury). See also Hydranautics, note 49, 204 F.3d at 887:

$[T]$ he existence of probable cause to institute legal proceedings precludes a finding that an antitrust defendant has engaged in sham litigation.... Under our decision today, therefore, a proper probable cause determination irrefutably demonstrates that an antitrust plaintiff has not proved the objective prong of the sham exception and that the defendant is accordingly entitled to... immunity.

${ }^{59} P R E$, note 14, 508 U.S. at 60 (citations omitted).

${ }^{60} 35$ U.S.C. § 102(b). 
sworn statement to the PTO that no such sales had occurred and years later brings an infringement action on this patent. Such a case, if the facts are sufficiently unambiguous, would serve to establish both the objective and the "subjective" motivation necessary, even though there is not additional evidence of subjective intent such as a memorandum between company officials stating "we are bringing this lawsuit even though we know that the on sale bar renders this patent unenforceable."

In Dippin' Dots the Federal Circuit appeared to read the PRE language much more literally. The infringement plaintiff's patent was rendered unenforceable by some 800 retail sales that occurred more than a year before the initial patent application was filed. ${ }^{61}$ The patentee neglected to disclose this information in its application, and the patentee's declaration contained a sworn statement that no such sales had occurred. Public sales made more than one year prior to filing bar patentability under $\$ 102(b)$ of the Patent Act, and also serve to make the patent "obvious" under $\$ 103 .{ }^{62}$ The court found that the information, if disclosed, would almost certainly have barred patentability and held the patent invalid. ${ }^{63}$

The court nevertheless held that the degree of inequitable conduct necessary to invalidate the patent was not as great as the degree needed to support an antitrust claim. In this case the only evidence of the patentee's anticompetitive intent was the fact that it had made the 800 sales over a one week period and then later swore to the PTO that the sales had not occurred. It subsequently also filed a patent infringement suit against those offending one or more of the claims made in the patent. The Federal Circuit held that

\footnotetext{
${ }^{61}$ Dippin' Dots, note 55.

${ }^{62}$ See 35 U.S.C. §§102(b), 103.

${ }^{63}$ See 476 F.3d at 1346 :
}

Absent explanation, the evidence of a knowing failure to disclose sales that bear all the earmarks of commercialization reasonably supports an inference that the inventor's attorney intended to mislead the PTO. The concealment of sales information can be particularly egregious because, unlike the applicant's failure to disclose, for example, a material patent reference, the examiner has no way of securing the information on his own. 
while this omission clearly qualified as inequitable conduct, it fell short of fraud in the Walker Process sense, which requires a stronger showing of both intent and materiality. ${ }^{64}$ In order to support a Walker Process antitrust case "there must be evidence of intent separable from the simple fact of the omission." ${ }^{65}$ The court observed:

It might be argued that because the omitted reference was so important to patentability, DDI [the patentee] must have known of its importance and must have made a conscious decision not to disclose it. That argument has some force, but to take it too far would be to allow the high materiality of the omission to be balanced against a lesser showing of deceptive intent by the patentee. Weighing intent and materiality together is appropriate when assessing whether the patentee's prosecution conduct was inequitable. However, when Walker Process claimants wield that conduct as a "sword" to obtain antitrust damages rather than as a mere "shield" against enforcement of the patent, they must prove deceptive intent independently. ${ }^{66}$

This approach re-creates some of the same difficulties of preMatsushita antitrust litigation under standards reluctant to grant

\footnotetext{
${ }^{64}$ Relying on Nobelpharma $A B$ v. Implant Innovations, Inc., 141 F.3d 1059, 1068-1069 (Fed.Cir.1998).

${ }^{65} 476$ F.3d at 1347 ("The difference in breadth between inequitable conduct and Walker Process fraud admits the possibility of a close case whose facts reach the level of inequitable conduct, but not of fraud before the PTO. This is such a case.").

${ }^{66} 476$ F.3d at 1348 (internal citations omitted). The court added:

While Walker Process intent may be inferred from the facts and circumstances of a case, "[a] mere failure to cite a reference to the PTO will not suffice." This is not to say that an omission always reduces to "mere failure to cite." We acknowledged in Nobelpharma "that omissions, as well as misrepresentations, may in limited circumstances support a finding of Walker Process fraud ... because a fraudulent omission can be just as reprehensible as a fraudulent misrepresentation." We believe, though, that to find a prosecution omission fraudulent there must be evidence of intent separable from the simple fact of the omission.
}

(citing and quoting Nobelpharma, 141 F.3d at 1070-1071). 
summary judgment, ${ }^{67}$ except in reverse. It requires extensive discovery through the patentee's documents for evidence of anticompetitive "intent" other than that manifested in the patent application itself. Further, it makes the infringement defendant's antitrust counterclaim dependent on the vagaries of the patentee's document retention policy or other efforts to suppress incriminating information, often attending pre-application activities that occurred many years prior to the litigation. For example, in Dippin Dots the sales found to invalidate the patent occurred in 1987. The subsequent patent infringement suit was filed in April of 2000, some thirteen years later. ${ }^{68}$ By that time the evidence of disqualifying sales could very well have been suppressed unless available from sources other than the patentee.

Further, the improper conduct was not limited to the misrepresentation to the PTO about prior sales; it also consisted in the subsequent filing of a patent infringement lawsuit, presumably designed to exclude the infringement defendant in the hopes that the disqualifying sales would not be discovered. Certainly one who files a patent infringement suit with present knowledge that the patent is unenforceable has met §2's conduct requirement.

\section{Objectively Unreasonable Patent Litigation}

\section{Patents of questionable validity or enforceability}

As noted above, PRE does not fully resolve the question of how to determine when a patent infringement suit is a "sham" which itself violates $\S 2$ of the Sherman Act. Patent infringement suits typically concern disputed issues of fact, most often going to patent validity, for which the "sham" analysis is different than it is for questions of law. Significantly, a complaint raising nothing more than a disputed question of law can frequently be disposed of without any discovery or trial. Disputes raising significant disputed fact issues often cannot be. ${ }^{69}$

${ }^{67}$ See 2 Phillip E. Areeda \& Herbert Hovenkamp, Antitrust Law $\uparrow 308$ (3d ed. 2007).

${ }^{68}$ See In re Dippin' Dots Patent Litigation, 249 F.Supp.2d 1346 (N.D.Ga.,2003) (docket entry).

${ }^{69}$ See Kemin Foods, L.C. v. Pigmentos Vegetales del Centro S.A. de C.E.V., 464 F.3d 1339 (Fed. Cir. 2006) (rejecting antitrust counterclaim to patent 
The lower courts have wrestled with this problem for some time, and have developed strict requirements for any infringement defendant claiming that the infringement action violated the antitrust laws. ${ }^{70}$ In Handgards the Ninth Circuit observed that an undue

infringement action based on claim that patentee falsely stated that certain of its products were covered by a particular patent claim when patentee had consistently maintained that they were covered and no court had adjudicated to the contrary; further, its legal position seemed plausible; also, antitrust counterclaimant alleged that patentee continued to warn former's customers of infringement even after counterclaimant notified patentee that it had changed its process so as to no longer infringe; patentee was entitled not to accept this notification at face value without proof); Netflix, Inc. v. Blockbuster, Inc., 2006-2 Trade Cas. \775484 (N.D.Cal. Aug. 22, 2006) (Blockbuster adequately alleged Walker Process violation in claim that Netflix committed fraud on PTO in acquiring business method patents and then filed bad faith infringement suit against rival; in particular Neflix failed to reference pre-existing patents held by a third party; that Netflix knew of these patents at the time it filed its own patent application; and that communication of the existence of these patents to examiner would have resulted in non-issuance of Netflix patents; court also concludes that Blockbuster adequately pled sham litigation as an "independent" basis for its antitrust lawsuit); Synopsys, Inc. v. Magma Design Automation, 2006 WL 1452803, 2006-1 Trade Cas. \75320 (D.Del. May 25, 2006) (plaintiff adequately pled that defendant used fraudulently obtained patents and public accusations of infringement and other disparagement to drive plaintiff out of business; rejecting defendant's claim that antitrust injury was not adequately pled).

Cf. Louisiana Wholesale Drug Co., Inc. v. Biovail Corp., 437 F.Supp.2d 79 (D.D.C. 2006) (defendant pioneer drug manufacturer could have violated antitrust laws by listing patent in orange book and announcing its own plans to make a generic version of its drug, thus ousting the plaintiff, a generic competitor, but then refusing to go ahead with the generic; however, ultimately concluding that statute of limitations barred the claim); General Physiotherapy, Inc., v. Sybaritic, Inc., 2006 WL 269991, 2006-1 Trade Cas. T75121 (E.D. Mo. Feb. 1, 2006) (defendants multiplication of trademarks and possible fraud in obtaining some of them could have violated §2; denying summary judgment); Gardner v. Clark, 101 F.Supp.2d 468 (N.D.Mis. 2000) (trademark infringement claim not objectively baseless).

${ }^{70}$ See, e.g., Dippin' Dots, note 55; Honeywell Intern. Inc. v. Universal Avionics Systems Corp., 488 F.3d 982 (Fed. Cir. 2007) (dismissing antitrust counterclaim where patent infringement action not shown to be objectively baseless); Q-Pharma, Inc. v. Andrew Jergens Co., 360 F.3d 1295 (Fed. Cir. 2004) (antitrust defendant's patent infringement suit was not objectively baseless even though infringement claim failed; defendant's interpretation of the patent claim in question was a reasonable one, and defendant was not required to give weight to letters from accused infringers asserting the patent's invalidity); BioTechnology General Corp. v. Genentech, Inc., 267 F.3d 1325 (Fed. Cir. 2001) (underlying patent infringement suit found not to be baseless; as a result, antitrust counterclaim dismissed); Proportion-Air, Inc. v. Buzmatics, Inc., 57 F.3d 1085, 
1995-2 Trade Cas. 771144 (Fed. Cir. unpub.) (same); Repeat-O-Type Stencil Mfg. Corp. v. Hewlett-Packard Co., 141 F.3d 1178 (9th Cir. 1998, unpublished), cert. denied, 525 U.S. 930 (1998) (antitrust complaint dismissed where infringement suit found not to be objectively baseless); Filmtec Corp. v. Hydranautics, 67 F.3d 931 (Fed. Cir. 1995), cert. denied, 519 U.S. 814 (1999) (even though patentee lost infringement suit, its claim was not objectively baseless); Carroll Touch, note 24, 15 F.3d at 1582-1583 (same).

See also Abbott Laboratories v. TEVA Pharmaceutical, Inc., 432 F.Supp.2d 408 (D.Del. 2006) (rejecting motion to dismiss; pioneer's patent litigation against generics could have been a sham); Wellbutrin SR Antitrust Litigation, 2006 WL 616292, 2006-1 Trade Cas. ๆ75158 (E.D.Pa. March 14, 2006) (under facts as alleged in complaint pioneer's patent infringement lawsuits against generic producer based on doctrine of equivalence would have been known to be frivolous; thus Walker Process claim survived motion to dismiss); Morton Grove Pharmaceuticals, Inc. v. Par Pharmaceuticals, Inc., 2006 WL 850873, 2006-1 Trade Cas. 975179 (N.D.III. March 28, 2006) (plaintiff adequately pled Walker Process claim based on knowing and wilful failures to disclose prior art at time of antitrust defendant's patent application, including an allegation that but for the failures to disclose the patent would not have issued; also approving "sham" litigation claim); Albert Hazelquist v. Guchi Moochie Tackle Co., Inc., 2004 WL 1599378, 2004-2 Trade Cas. 174,498 (W.D. Wash., May 12, 2004) (trade dress; patentee originally represented to patent office that fishing tackle device was purely ornamental when in fact it had a function; this was not fraud sufficient to make its subsequent infringement claim a Walker Process violation); Honeywell Intl., Inc. v. Universal Avionics Sys. Corp., 343 F. Supp. 2d 272 (D. Del. 2004) (rejecting antitrust counterclaim where underlying patent infringement suit was not objectively baseless); Applera Corp. v. MI Research, Inc., 303 F.Supp. 2d 130 (D. Conn. 2004) (evidence that patent owner had threatened infringement suits against other firms in order to obtain licenses and that its motives may have been anticompetitive was irrelevant if its current infringement action was not objectively baseless); Terazosin Hydrochloride Antitrust Litigation, 335 F. Supp. 2d 1336 (S.D. Fla. 2004) (brand-name manufacturer's attempts to enforce its pharmaceutical patents were not objectively baseless); Bristol-Myers Squibb Co. v. Ben Venue Labs., 90 F.Supp.2d 540 (D.N.J. 2000) (finding fact issue whether infringement plaintiff had obtained patent by fraud; denying summary judgment on antitrust counterclaim); Ecrix case, note 38 (requiring discovery on issue whether infringement plaintiff had reasonable basis for concluding that infringement defendant's technology actually infringed); Hoffman-La Roche, Inc. v. Genpharm, Inc., 50 F.Supp.2d 367 (D.N.J. 1999) (question whether patents allegedly infringed by defendant's suit were unenforceable and suit brought only to obtain infringement defendant's trade secrets could not be resolved on motion to dismiss); Baxa Corp. v. McGaw, Inc., 996 F.Supp. 1044 (D.Co. 1998), aff'd 185 F.3d 883 (Fed. Cir. 1999) (no antitrust violation where patent was not shown to be procured by either fraud or inequitable conduct before the Patent and Trademark Office); Independent Serv. Org. Antitrust Litig., 964 F.Supp. 1479 (D.Kan. 1997) (filing of patent infringement counterclaims not an antitrust violation where the counterclaims could not be characterized as objectively baseless).

Related decisions include Marketing Displays, Inc. v. Traffix Devices, Inc., 
readiness to hold an infringement suit improper would diminish the protection afforded by patent grants, contrary to their purpose. ${ }^{71}$ To avoid that danger, the court presumed that patent infringement actions are reasonably brought and the antitrust plaintiff can defeat this presumption only by clear and convincing evidence. ${ }^{72}$ Similarly,

200 F.3d 929 (6th Cir. 1999), rev'd on nonantitrust issue, 532 U.S. 23 (2001) (because trade dress rights can last beyond the expiration of patent rights, bringing of a trade dress infringement suit after patent had expired was not a "sham"). Cf. Undersea Breathing Sys., Inc. v. Nitrox Tech., Inc., 985 F.Supp. 752 (N.D.IIl. 1997), app. dism'd, 155 F.3d 1574 (Fed. Cir. 1998) (infringement defendant could not show that infringement action constituted patent misuse or antitrust violation where there was only weak evidence suggesting that patentee had failed to disclose all prior art at time of application; court ultimately found insufficient evidence that patent was invalid, but also no infringement); Publications Intl. Ltd. v. W. Publishing Co., 1994 WL 23008, 1994-1 Trade Cas. I70,540 (N.D. III. 1994) (monopolization possible if market-dominating patent obtained by fraud for nonpatentable invention but appearing to have sufficient "colorable validity" to intimidate actual or potential rivals; refusal to dismiss complaint even though plaintiff alleged relevant market of "electronic storybooks," within which market there were apparently numerous non-infringing products); see also Agere Sys. Guardian Corp. v. Proxim, Inc., 190 F.Supp. 2d 726 (D. Del. Mar. 6, 2002) (antitrust counterclaimant sufficiently pled that infringement plaintiff was attempting to enforce patent obtained by fraud).

And see Andrx Pharmaceutical, Inc. v. Elan Corp., PLC, 421 F.3d 1227 (11th Cir. 2005) (rejecting antitrust claim that patent infringement suit was fraudulent because patent was not enforceable due to on-sale bar, where two other courts had already concluded that the on-sale bar did not apply so as to defeat the patent); Porous Media Corp. v. Pall Corp., 186 F.3d 1077 (8th Cir. 1999) (Noerr and PRE protected filing of trademark and trade dress infringement counterclaims when these were found not to be objectively baseless); Novo Nordisk of N. America v. Genentech, Inc., 885 F.Supp. 522 (S.D.N.Y. 1995) (patentee's infringement claim before international agency not objectively baseless simply because the claim was ultimately dismissed for discovery-related misconduct; magistrate had found some evidence of infringement).

${ }^{71}$ Handgards, Inc. V. Ethicon, Inc. (Handgards I), 601 F.2d 986 (9th Cir. 1979), cert. denied, 444 U.S. 1025 (1980).

${ }^{72}$ The antitrust plaintiff later succeeded in doing so. Handgards, Inc. v. Ethicon, Inc. (Handgards II), 743 F.2d 1282 (9th Cir. 1984), cert. denied, 469 U.S. 1190 (1985). Because proving the patentee's bad faith for this purpose necessarily proved a "sham" exception to Noerr's privilege to sue, the court also held that requiring a jury instruction on the Noerr issue would be duplicative. Id. at 1295.

The Federal Circuit followed the Ninth Circuit in Loctite Corp. v. Ultraseal Ltd., 781 F.2d 861 (Fed. Cir. 1985). See also FMC Corp. v. The Manitowoc Co., 654 F. Supp. 915 (N.D. III.), aff'd, 835 F.2d 1411 (Fed. Cir. 1987) (requiring clear and convincing evidence); Tennant Co. v. Hako Minuteman, 651 F. Supp. 945 
the Federal Circuit emphasized that every patent enjoys a strong presumption of validity, ${ }^{73}$ and the one seeking to show invalidity has the burden of proof. ${ }^{74}$ The court further declared that one challenging an infringement action on an invalid patent as an antitrust violation must show specific intent, not merely negligence or even recklessness with respect to the invalidity of the patent. ${ }^{75}$ That requirement seems consistent with the PRE requirement, discussed above, that the inquiry into "sham" consist of two parts. First, one must determine on the basis of objective information whether the infringement suit was unreasonable under the circumstances. Second, and "[o]nly if challenged litigation is objectively meritless may a court examine the litigant's subjective motivation. ${ }^{176}$

The infringement plaintiff's subjective knowledge that a patent is invalid or unenforceable would make an enforcement suit exclusionary, as would its knowledge that the patent is otherwise unenforceable because of the patentee's misuse or some other equitable factor. However, the difficulty of knowing when a court will deem a valid patent unenforceable means that we can seldom find the infringement suit improper merely because a court refuses to enforce a valid patent. Thus the Eighth Circuit found no antitrust

(N.D. III. 1986) (same).

${ }^{73}$ As provided by 35 U.S.C. $\$ 282$ (providing that both patent as a whole and each individual claim made in a patent enjoys presumption of validity, even if another claim has proved to be invalid; burden of proof on person alleging invalidity).

${ }^{74}$ American Hoist \& Derrick Co. v. Sowa \& Sons, 725 F.2d 1350, 1359 (Fed. Cir.), cert. denied, 469 U.S. 821 (1984). See also Technicon Instruments Corp. v. Alpkem Corp., 866 F.2d 417 (Fed. Cir. 1989) (mere bringing of a single infringement action on patent subsequently found invalid does not establish antitrust violation); Carlisle Corp. v. Hayes, 635 F. Supp. 962 (S.D. Cal. 1986).

${ }^{75} 725$ F.2d at 1368.

${ }^{76}$ PRE, note 14 at 1928. See Scientific Drilling Intl v. Gyrodata Corp., 215 F.3d 1351, 1999 WL 674511 (Fed.Cir. 1999, unpublished) (since it had not yet been determined whether infringement plaintiff's suit was objectively baseless, it was premature to dismiss antitrust counterclaim); Hunter Douglas, Inc. $v$. Comfortex Corp., 44 F.Supp.2d 145 (N.D.N.Y. 1999) (on pretrial motion, separating patent infringement trial from antitrust counterclaim trial, because patentee's success on the first would make the second unnecessary). Accord Ecrix Corp. v. Exabyte Corp., 191 F.R.D.611 (D.Colo. 2000). 
violation when a firm sued to enforce a patent that was valid but determined to be unenforceable because of the patentee's "unfair" conduct. $^{77}$ Similarly, the antitrust defendant in Argus had engaged in inequitable conduct before the patent office by failing to disclose sales of the patented product that had been made more than one year before the application was filed. ${ }^{78}$ The court declined to find an antitrust violation without proof of "knowing and willful patent fraud" that is "based on the use of an invalid patent to monopolize. ..."79 And the FMC court held that "inequitable conduct" before the patent office is not enough, for negligent or even grossly negligent failure to disclose a material fact that might have led to nonissuance of a patent showed no more than "inequitable conduct." ${ }^{80}$ Fraud requires knowledge and specific intent to obtain an undeserved patent.

Clearly, however, if the antitrust defendant knew it was not entitled to relief because its patent was not enforceable, then its conduct could be both exclusionary and unprotected by either Noerr ${ }^{81}$ or PRE. In sum, obtaining a patent by inequitable conduct falling short of fraud is not an antitrust violation; but bringing an infringement action with the subjective or readily discoverable knowledge that the patent is unenforceable may constitute a violation.

${ }^{77} d u$ Pont v. Berkley \& Co., 620 F.2d 1247, 1273-1275 (8th Cir. 1980).

${ }^{78}$ Argus Chem. Corp. v. Fibre Glass-Evercoat Co., 812 F.2d 1381 (Fed. Cir. 1987); accord Dippin' Dots, note 55.

${ }^{79}$ Id. at 1385, quoting SSP Agric. Equip., Inc. v. Orchard-Rite Ltd., 592 F.2d 1096, 1103-1104 (9th Cir. 1979).

${ }^{80}$ FMC, note 72, 835 F.2d at 1415 \& n.9. See also Korody-Colyer Corp. $v$. General Motors Corp., 828 F.2d 1572 (Fed. Cir. 1987); Minn. Mining \& Mfg. v. Research Medical, 691 F. Supp. 1305 (D. Utah 1988) (antitrust plaintiff must show "intentional fraud in the common law sense": misrepresentation of a material fact going to the validity of the patent with knowledge of its falsity and reliance by the Patent Office on this misrepresentation in issuing the patent). Cf. Glaverbel Society Anonyme v. Northlake Mktg. \& Supply, Inc., 45 F.3d 1550 (Fed. Cir. 1995) (defendant did not procure patent fraudulently or even engage in inequitable conduct when its initial patent application failed to refer to two similar patents, but the initial application was not required to do so; and where the company subsequently narrowed the scope of its patent upon patent office's re-examination; none of this came close to proving intent to deceive by clear and convincing evidence).

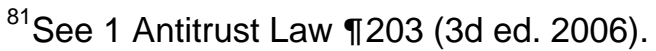


Finally, the antitrust defendant is entitled to summary judgment unless the evidence shows that the facts necessary to support the antitrust plaintiff's claim are more likely than not to be true. $^{82}$ This means not merely that the evidence must be consistent with the defendant's possession of the requisite knowledge or intent, but also that the evidence justifies the conclusion that such possession was more probable than not. Nonetheless, some courts continue to be quite reluctant to grant summary judgment. ${ }^{83}$

\section{Patent valid but not infringed}

The same considerations discussed previously generally apply when the patent in question is of undisputed validity, but the infringement plaintiff took insufficient steps to ensure that the infringement defendant was actually an infringer. ${ }^{84}$ Of course, the patentee may have been careless. But the monopolist might pursue a policy of protecting its market by launching a lawsuit against every rival product appearing on the scene, without regard to actual infringement, and simply to deter small rivals from entering.

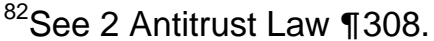

${ }^{83}$ E.g., Carlisle, note 74 at $965-967$ (refusing summary judgment even though there was no evidence offered of fraud on the patent office by the antitrust defendant, but merely of some controversy as to the state of the prior art). See also ID Security Systems Canada, Inc. v. Checkpoint Systems, Inc., 249 F. Supp. 2d 622 (E.D. Pa. 2003), amended by 268 F.Supp. 2d 448 (E.D. Pa. 2003) (troublesome dicta that evidence of patentee's previous patent infringement actions were admissible on question of anticompetitive intent, even though there was no evidence that the infringement actions were improper; relying on Kobe, Inc. v. Dempsey Pump Co., 198 F.2d 416, 425 (10th Cir. 1952), cert. denied, 344 U.S. 837 (1953); ultimately dismissing claim on market power grounds); Applera Corp. v. MJ Research, Inc., 309 F. Supp. 2d 293 (D. Conn. 2004) (evidence that patent owner priced licenses for its two patents in a way that forced licensees to take both even if they only wanted one was admissible relevant to antitrust counterclaim to infringement action, as well as patent misuse defense).

${ }^{84}$ The question of claim construction is closely related. In general, the scope of the "claim" made in the patent application presents a question of law. See Markman and other decisions cited in note 40. In such cases the infringement defendant may not dispute the validity of the patent but alleges that it is not an infringer because the claim is to be construed more narrowly than the infringement plaintiff alleges. 
The PRE objective standard asks mainly whether the patentee exercised reasonable care in determining the fact of infringement. Although we cannot discuss the many possibilities, a few illustrations and principles may be stated.

When the monopolist is vindicating a product patent, we can at least insist that it inspect the allegedly infringing article and draw a reasonable conclusion of infringement before filing its infringement suit or taking other actions, such as writing letters to customers, that might injure the alleged infringer's market position. ${ }^{85}$ This restriction applies regardless of any sincere belief the monopolist might have about the impossibility of a non-infringing product in its field. ${ }^{86}$

The product itself may not reveal the presence or absence of an infringed process patent. In that case, the monopolist should be compelled to request a reasonable opportunity to inspect the allegedly infringing process before attacking. Once these preliminaries have occurred, we hesitate to appraise too precisely the monopolist-patentee's judgment about infringement -- especially in an infringement suit where the infringement defendant might want to divert the suit from the question of infringement to the plaintiff's reasonableness in suing. The patentee should not be forced to sue at its peril. Yet, neither should its discretion be completely immune from review. Accordingly, we conclude that a monopolist-patentee's judgment in attacking an infringer may be tested for reasonableness in any appropriate suit, but the alleged infringer must overcome a presumption of reasonableness in favor of a patentee whose behavior appears reasonable on its face. We emphasize that issues concerning the legal question of infringement and the facts that constitute it are to be addressed directly under the patent laws.

${ }^{85}$ The court did so insist in Kobe v. Dempsey Pump Co., 198 F.2d 416, 424 (10th Cir.), cert. denied, 344 U.S. 837 (1952). See also Ecrix, note 38, 95 F.Supp.2d 1155 (permitting antitrust plaintiff discovery into factual basis for infringement plaintiff's allegation that former's technology infringed the latter's patent).

${ }^{86}$ Such a rule might be thought futile because antitrust law is not likely to interfere very effectively with a patentee's propensity to sue once it goes through the motions of inspecting the allegedly infringing article. But even if some patentees sue with undetected bad faith, encouraging proper forms of conduct can beneficially influence the substance of behavior. This limited intervention, moreover, may threaten an appraisal of the patentee's judgment in suing and thereby deter some undesirable conduct. 


\section{Government guidelines}

Guidelines issued by the Justice Department set forth the circumstances under which it will prosecute a patent infringement action as unlawful monopolization. ${ }^{87}$ Somewhat inconsistently, those Guidelines provide that "Enforcement of a patent obtained by mere inequitable conduct before the Patent and Trademark Office, however, cannot be the basis of a section 2 claim, because inequitable conduct does not involve knowing and willful patent fraud" but also that "An objectively baseless infringement action, brought in bad faith, when the complainant knows the intellectual property right to be invalid, may violate section 2 of the Sherman Act." ${ }^{88}$ As indicated earlier, we believe that the second of these propositions is the more accurate statement of the law.

\section{Antitrust Challenge as Compulsory or Permissive Counterclaim; Declaratory Judgment and Direct Action Alternatives}

\section{Counterclaim}

In most cases the antitrust challenge to an infringement action is presented as a counterclaim to the infringement suit itself. If such counterclaims are classified as "compulsory" they must be brought as counterclaims or will be barred by principles of res judicata. If, however, the antitrust counterclaim is permissive then failure to bring it will not preclude a subsequent and independent antitrust challenge to the infringement action. ${ }^{89}$

${ }^{87}$ See Antitrust Guidelines for the Licensing and Acquisition of Intellectual Property $\$ 6.0$ (1995), reprinted in 59 Fed. Reg. 41,339. These Guidelines are reprinted as Appendix $\mathrm{C}$ to the Supplement.

${ }^{88}$ Id. at $§ 6$.

${ }^{89}$ See Federal Rule of Civil Procedure 13(a), which states in relevant part:

A pleading shall state as a counterclaim any claim which at the time of serving the pleading the pleader has against any opposing party, if it arises out of the transaction or occurrence that is the subject matter of the opposing party's claim and does not require for its adjudication the presence of third parties of whom the court cannot acquire jurisdiction.

See 6 Charles A. Wright, Arthur R. Miller, \& Mary K. Kane, Federal Practice \& Procedure \$1417 (Civ. 2d 1990 \& 2008 Supp.); Michael D. Conway, Comment, 
The trend is to find such counterclaims to be compulsory and thus barred if not timely brought during the pendency of the infringement suit. The Second Circuit's Critical-Vac decision distinguished between antitrust counterclaims to the infringement suit, which should be treated as compulsory, from claims and defenses of patent misuse, which might be treated as permissive. ${ }^{90}$ The Supreme Court's controversial Mercoid decision ${ }^{91}$ had treated the latter as permissive, and the Second Circuit felt obliged to reconcile it with emergent doctrine holding that antitrust counterclaims to infringement actions are best regarded as compulsory. It reasoned:

Antitrust claims based on patent misuse, such as the counterclaims in Mercoid, are likely to involve factual issues distinct from those involved in patent infringement litigation

Narrowing the Scope of Rule 13(A), 60 U. Chi. L. Rev. 141, 156 (1993).

On related procedural issues see Arthrocare Corp. v. Smith \& Nephew, Inc., 406 F.3d 1365 (Fed. Cir. 2005) (refusing to dismiss antitrust counterclaim until antitrust plaintiff could respond on baselessness issue); Donnelly Corp. v. Reitter \& Schefenacker, USA, 2002 WL 31418042, 2002-2 Trade Cas. ๆ 73,817 WD. Mich. Aug. 13, 2002) (granting infringement plaintiff's request to bifurcate trial of infringement claim and patent counterclaim; but not to stay discovery on the counterclaim; permitting all discovery to go forward would prevent discovery disputes and facilitate settlement).

${ }^{90}$ Critical-Vac Filtration Corp. v. Minuteman Int1, Inc., 233 F.3d 697 (2d Cir. 2000), cert. denied, 532 U.S. 1019 (2001). See also Eon Labs, Inc. v. SmithKline Beecham Corp., 298 F. Supp. 2d 175 (D. Mass. 2003) (antitrust challenge to patent infringement suit is compulsory counterclaim; following Critical-Vac); Jarrow Formulas v. International Nutrition Co., 175 F.Supp. 2d 296 (D. Conn. 2001) (distinguishing Critical-Vac decision discussed in the main text: where some of the facts supporting the antitrust claim occurred after resolution of prior patent infringement suit, the antitrust claim could not be treated as a compulsory counterclaim to that prior suit). Cf. Xerox Corp. v SCM Corp., 576 F.2d 1057, 1061 (3d Cir. 1978) (antitrust counterclaim not compulsory as to large antitrust suit challenging many aspects of defendant's conduct). But when the underlying claim is simply for infringement and the basic defense to the infringement action is essentially the same as the counterclaim, the latter is compulsory. Accord Koufakis v. Carvel, 425 F.2d 892, 898 (2d Cir. 1970); United Artists Corp. v. Masterpiece Prods., Inc.., 221 F.2d 213, 216 (2d Cir. 1955). See 6 Wright, Miller \& Kane, note 89 at $\S \$ 1411-1412$.

\footnotetext{
${ }^{91}$ Mercoid Corp. v. Mid-Continent Inv. Co., 320 U.S. 661 (1944).
} 
between the same parties... In contrast, antitrust claims based on patent invalidity, such as C-Vac's claims in the instant case, will generally involve the same factual issues as those involved in patent infringement litigation between the same parties.... ${ }^{92}$

This reasoning is not entirely persuasive. Some misuse claims raise precisely the same issues as arise in an antitrust claim and all necessary facts are known to the infringement defendant at the time of the infringement suit. For example, perhaps the infringement plaintiff requires the defendant to use tied, staple commodities with the patent and its failure to do so forms the basis for the infringement claim. ${ }^{93}$ In such cases there is no reason not to make the antitrust counterclaim compulsory. In other cases -- such as when the patent is procured by fraud but the facts are not revealed until after the infringement suit has run its course -- justice is poorly served by a rule that prevents a subsequent antitrust challenge. ${ }^{94}$

When the facts supporting the antitrust counterclaim are the same as those supporting the infringement defense, a compulsory counterclaim rule economizes on judicial resources and tends toward the efficient resolution of disputes. For example, if the defense is that the theory of infringement is legally frivolous, the patent is clearly invalid or has expired, or the defendant's technology is obviously not infringing, then many of the facts necessary to support the antitrust counterclaim are implicit in the defense itself. Other facts, such as market power or the dangerous probability of success in achieving it can be developed through discovery.

Making antitrust counterclaims compulsory is less sensible, however, when the facts needed to support the counterclaim are not sufficiently known at the time the infringement action is brought. In such cases a compulsory counterclaim rule requires the infringement defendant to bring an antitrust claim that would be treated as

${ }^{92}$ Critical-Vac, 223 F.3d at 703. See also USM Corp. v. SPS Technologies, Inc.102 F.R.D. 167 (N.D. Ill. 1984) (making the same distinction).

${ }^{93}$ See 10 Antitrust Law $₫ 1781 b, d$.

${ }^{94}$ For fuller treatment, see Hovenkamp, Janis \& Lemley, note 40 at $§ 5.5$. 
unfounded or even frivolous if brought through the usual process. The outcome is particularly serious if the facts needed to support the antitrust counterclaim are not known until after the filing deadline for counterclaims has passed or, worse yet, after the trial is over. ${ }^{95}$

As a result, some allowance must be given to an infringement defendant forced to file its antitrust counterclaim before the full facts or the full impact of any antitrust violation is known. For example, it would be perverse to hold that an antitrust claim is compulsory and thus cannot be brought later, but also that the infringement defendant lacks standing to bring the antitrust counterclaim because it has not yet perfected entry into the market. ${ }^{96}$

\section{"Affirmative" use of Walker Process: suits under Declaratory Judgment Act or direct Sherman Act suits}

A counterclaim naturally presupposes an underlying infringement claim to which it is attached. If the owner of an improperly obtained patent institutes enforcement actions falling short of an infringement suit, then the target's only recourse may be to institute their own action. The Declaratory Judgment Act $^{97}$

\footnotetext{
${ }^{95}$ See American Packaging Corp. v. Golden Valley Microwave Foods, Inc., 1995 WL 262522, 1995-1 Trade Cas. \71,009 (E.D. Pa. 1995) (infringement defendant claimed that information about fraudulent procurement of patent became available only very late in the infringement suit); see also Hydranautics, note 49, 204 F.3d at 886 (infringement defendant properly pled that infringement plaintiff committed perjury at infringement trial and that in absence of perjured testimony it would have lacked probable cause to pursue infringement action).

If new facts emerge after the litigation or if the infringement plaintiff committed fraud or other misconduct, Federal Rule of Civil Procedure 60b1 permits the judge to give a party relief from the judgment provided that motion is made within a reasonable time, or within one year after entry of judgment.

${ }^{96}$ Cf. Amgen, Inc. v. F. Hoffman-La Roche LTD, 2007-1 Trade Cas. 175766 (D.Mass. March 30, 2007) (rival who was target of patent infringement actions had standing to assert counterclaim even though it was not yet producing in the market, where FDA approval was "imminent" -- better rule here, if the infringement defendant is close enough to entry that a patent infringement suit or threat of it is forthcoming, then it has standing to maintain the antitrust action; further, expenses of litigating the patent could constitute "antitrust injury").

${ }^{97} 28$ U.S.C. \$2201. What we say here is not intended to be a comprehensive treatment of Declaratory Judgment actions in this legal setting. For that, see 10B Charles A. Wright, Arthur R. Miller, \& Mary Kay Kane, Federal
} 
contemplates such actions, ${ }^{98}$ and some courts have permitted a direct antitrust challenge under the Sherman Act.

For example, in Unitherm that patentee wrote threatening letters to numerous firms, including customers of the challenger. ${ }^{99}$ The claimant brought a Declaratory Judgment action asserting Walker Process-like claims, and the Federal Circuit concluded that a plaintiff in the claimant's position "may bring a Declaratory Judgment Action of patent invalidity ... even in the absence of overt enforcement actions. ${ }^{100}$ The Federal Circuit observed that merely obtaining a patent whose claims conflicted with the technology of the Declaratory Judgment plaintiff would be insufficient to raise the type of threat of harm that the Declaratory Judgment Act contemplated. However, threatening communications, even if not directed at the claimant itself, could be sufficient. Just as the mere obtaining of a patent, with no subsequent enforcement activity, would not violate Walker Process, so too it would not give rise to a Declaratory Judgment action. ${ }^{101}$

In Hydril the Federal Circuit went one step further, holding that a firm could file a Sherman Act lawsuit directly against a patentee who had threatened the antitrust plaintiff's customers and supplier after widely publicizing its patent in the market, even though it knew that the patent was invalidated by prior art. ${ }^{102}$ The Federal Circuit

Practice and Procedure, §2751-2759 (Civ. 3d 2007).

${ }^{98}$ See MedImmune, Inc. v. Genentech, Inc., 127 S.Ct. 764 (2007), holding that a licensee did not need to repudiate its license agreement as a condition of having a "case or controversy" sufficient to invoke the Declaratory Judgment Act.

${ }^{99}$ Unitherm, note 20.

${ }^{100}$ Id., 375 F.3d at 1358. See also Highway Equipment Co., Inc. v. Cives Corp., 476 F.Supp.2d 1079 (N.D.Ia. 2007).

${ }^{101}$ See, e.g., Microchip Technology Inc. v. The Chamberlain Group, 441 F.3d 936 (Fed.Cir.2006) (no jurisdiction under Declaratory Judgment Act when DJ plaintiff did not face reasonable apprehension of suit).

${ }^{102}$ Hydril Co. LP v. Grant Prideco LP, 474 F.3d 1344 (Fed. Cir. 2007). Contrast Merchandising Technologies, Inc. v. Telefonix, Inc., 2007-1 Trade Cas. I75598 (D.Ore. Feb. 7, 2007) (minimum degree of enforcement necessary to support Walker Process claim is that needed to establish actual controversy for purposes of declaratory judgment act; here not even enough controversy to establish that; in fact, the patentee had simply sent out to its customers a notice of 
rejected the district court's conclusion that an affirmative claim would lie only if the patentee's enforcement action lay against the antitrust claimant itself, as would normally be the case in a Declaratory Judgment Action. The court observed:

To the extent the district court's ruling may have been based on Hydril's failure to allege threatened enforcement action against Hydril rather than against its customers, a valid Walker Process claim may be based upon enforcement activity directed against the plaintiff's customers. Threats of patent litigation against customers, based on a fraudulentlyprocured patent, with a reasonable likelihood that such threats will cause the customers to cease dealing with their supplier, is the kind of economic coercion that the antitrust laws are intended to prevent. A supplier may be equally injured if it loses its share of the market because its customers stop dealing with it than if its competitor directs its monopolistic endeavors against the supplier itself. Without customers, a supplier has no business. ${ }^{103}$

the existence of its patent).

Of course, consumers as well as competitors can bring direct actions. See Netflix Antitrust Litigation, 2007-1 Trade Cas. \75749 (N.D.Cal. June 14, 2007) (consumers had standing to challenge alleged Walker Process violation; ultimately deciding that the plaintiffs failed to state a claim; allegations were merely that Netflix obtained its patents fraudulently; plaintiffs could not show that any rival was actually excluded by the patents); Molecular Diagnostics Labs. V. Hoffmann-La Roche, Inc., 402 F. Supp. 2d 276, 280 (D.D.C. 2005) (purchasers have standing). Cf. DDAVP Direct Purchaser Antitrust Litigation, 2007-1 Trade Cas. \75726 (S.D.N.Y. Nov. 2, 2006) (odd, apparently incorrect alternative holding that direct purchasers of drug lacked standing to assert Walker Process claim alleging that defendant used improperly procured patent to keep generics off market resulting in higher prices for its own drug; court holds that because Walker Process is founded in patent, only infringement defendant/competitor has standing to assert it; but if §2 is violated and results in higher prices, consumers are clearly appropriate plaintiffs). The language from Walker Process that the DDAVP court cites states only that enforcement of a fraudulently obtained patent is exclusionary vis-a-vis the competitor/infringement defendant; but all exclusionary practices fit into that classification).

${ }^{103} \mathrm{Id}$. at 1350 . On remand the district court dismissed the complaint once again, declaring mainly that the plaintiff lacked standing because it had shown insufficient intent and preparedness to enter the market covered by the patent. Hydril Co. v. Grant Prideco, L.P., 2007-2 Trade Cas. \75769 (S.D.Tx. June 19, 2007). 


\section{Remedies}

The antitrust violation for an improper infringement suit presupposes that the patent in question is either invalid or unenforceable, or else that the infringement defendant's technology does not infringe. As a result, remedies such as compulsory licensing are generally inapt. No one needs a license to copy the technology described in an invalid patent; nor does the person whose technology does not infringe. At the very least, antitrust remedies can include an injunction against future, similar conduct. But in most cases such a remedy would not be of much value.

Probably the most appropriate remedy is damages to the infringement defendant (or potential infringement defendants) whose entry, growth, or sales have been stifled by the infringement plaintiff's wrongful conduct. Currently the circuit courts are divided on the question whether the costs of defending a wrongfully brought infringement action subsequently found to be an antitrust violation are recoverable as antitrust damages. ${ }^{104}$

On principle, the cases permitting such damages seem correct. Infringement suits are designed to raise the entry costs of rivals, and clearly the cost of defending such suits is part of the "cost" of entry. Further, of all the damages suffered by such plaintiffs -- loss of sales, loss of market share, loss of prospective entry opportunities -- the costs of litigating the infringement suit are by far the most certain and easy to measure.

On Hydril, see Christopher R. Leslie, New Possibilities for Asserting Walker Process Claims, 21 Antitrust 48 (Summer, 2007).

${ }^{104}$ See Ansul Co. v. Uniroyal, Inc., 448 F.2d 872, 882-883 (2d Cir. 1971), cert. denied, 404 U.S. 1018 (1972) (denying such recovery); Premier Elec. Constr. Co. v. Nat'l Elec. Contractors Assn., 814 F.2d 358, 371-372 (7th Cir. 1987) (permitting it); Handgards II, note 72, 743 F.2d at 1297-1298 (same); Kearney \& Trecker Corp. v. Cincinnati Milacron, 562 F.2d 365, 374 (6th Cir. 1977) (same); Am. Infra-Red Radiant Co. v. Lambert Indus., Inc., 360 F.2d 977 (8th Cir.), cert. denied, 385 U.S. 920 (1966) (same); Hynix Semiconductor Inc. V. Rambus, Inc., 527 F.Supp.2d 1084 (N.D.Cal. 2007); Marchoti Eyezvear v. Tura LP, 2002 WL 31253199 (E.D.N.Y. Sept. 30, 2002) (same); IGT v. Alliance Gaming Corp., 2007-1 Trade Cas. I75687 (D.Nev. March 22, 2007) (same); Van Well Nursery, Inc. v. Mony Life Insurance Co., 2007-1 Trade Cas. ๆ75705 (E.D.Wash. March 6, 2007) (same). 
Of course, damages need not be limited to the costs of defending the improper suit. Such suits may also cause loss of sales, premature exit from the market, precluded entry, all of which invoke more traditional measures of damages. 